curvature and $\mathrm{I}_{5} 5$ inch diameter, the following results were obtained with 8,040 cells :-

\begin{tabular}{|c|c|c|c|c|}
\hline Pressure. & $\left\{\begin{array}{c}\text { Fraction of an } \\
\text { atmosphere. }\end{array}\right.$ & $\begin{array}{l}\text { Length of } \\
\text { spark. }\end{array}$ & $\begin{array}{l}\text { Ratio to } \\
\text { length at I } \\
\text { atmosphere. }\end{array}$ & $\begin{array}{l}\text { Ratio of length of } \\
\text { spark to dilatation }\end{array}$ \\
\hline $\begin{array}{l}\text { Millims. } \\
760\end{array}$ & 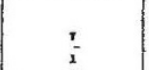 & $\begin{array}{l}\text { Inch. } \\
\text { 0.079 }\end{array}$ & 1.00 & $\frac{x}{x}=r^{\prime} \cdot 000$ \\
\hline $6 \odot 2$ & & 0.100 & $1 \cdot 26$ & $\frac{x^{2}}{x^{2} 262}=0^{\prime} .999$ \\
\hline $4^{1} 4^{\circ} 7$ & $\frac{x}{x \cdot 833}$ & 0.200 & $2 \cdot 52$ & $\frac{2^{\prime} 5^{2}}{x^{\prime} 833}=1^{*} 375$ \\
\hline $299^{\circ} 5$ & $\frac{x}{2537}$ & 0.400 & $5^{*} \times 4$ & $\frac{504}{2.537}=1.986$ \\
\hline$I_{4} I \cdot 5$ & $\frac{x}{5370}$ & 0.800 & 10.08 & $\frac{7008}{5.370}=I .876$ \\
\hline
\end{tabular}

\section{ERNEST QUETELET}

THE death of M. Ernest Quetelet, "chef du service Astronomique " of the Observatory of Brussels, took place at Ixelles on the 6th instant, after a long and painful illness. His connection with the observatory dates from 1855, when he entered it as an assistant to his father, the late Lambert Adolphe Jacques Quetelet, who was then the director, and who died so recently as February, 1874. Ernest was born in Brussels August 7, 1825. At that time his father was busily occupied in pressing on the king and the municipality of Brussels the importance of establishing an observatory for meteorological purposes. After much discussion and many delays it was determined in 1826 to establish an astronomical observatory; Quetelet was directed to obtain instruments, to visit Paris and London, and on January 9, I 828 , he received his official appointment, his title being "astronomer." The three principal astronomical instruments were set up in 1835 , but the first four volumes of the Annales of the observatory coming down to 1845 contain only meteorological notes. The first rolume (date 1834) opens with an "aperçu historique des observations de météorologie faites en Belgique jusqu'à ce jour," commencing with 1763, and shows how thoroughly the director entered into the importance of the work. The observatory in 1845 was the centre of meteorological observing stations, of which there were more than eighty.

Although Ernest, as he grew up, shared his father's interest in the various observations included under the head meteorological, and took terrestrial magnetism as a special subject for study, on joining the observatory in I 855 he was appointed to take the astronomical observa tions and the Annales record that the observations were made by him and the calculations of the reductions by M. L. Estourgies. From 1857 he has had in liand the revision of a catalogue of the variable stars, a large part of which has been published. Two years ago he issued the climatological elements of Brussels, in a series of eighteen tables, for the ten years ending 1873 , and in the Bulletin of the Societé Royale are many papers by him on magnetism.

Before entering the observatory he was in the Engineers for several years, after having passed through the École Militaire of Brussels. In 1848 he was engaged as a subaltern on the work of the fortifications of Antwerp. It was while still in the Engineers he communicated his first paper to the Academy, "Recherches sur les Médianes" (October 9, 1859), which was printed in the Mémoirs Couronnés. In 1856 , shortly after joining the Observatory, he wrote a paper on the magnetism of the earth in North Germany and Holland, and in 1859, "On the Magnetic Declination at Brussels."

The Observatory has all through its existence had to struggle against difficulties; one of the latest recommendations of the Commission on it was to effect the following improvements :-
"To complete the magnetic system of the Observatory by the acquisition of self-registering instruments, to organise the International Meteorological Service, to obtain an equatorial of large dimensions with the accessories necessary to the spectroscopic investigation of the heavens, and to increase the number and improve the position of the observer."

During many years M. Quetelet has often been appointed referee to the printing of papers in the Mémoires of the Académie Royale, and has been himself a frequent contributor.

\section{GEOGRAPHICAL NOTES}

IN the Geographical Section of the French Association some papers of interest were read. Dr. Carret read a curious paper on the Distribution of Antipodes, in which the author indulged in some rather fanciful theorising. Gen. Ricci spoke on the geodetic work carried on by the Italian Government, which is energetically completing the triangulation of Italy, connecting it with the rest of Europe on the one side and Africa on the other. Gen. Ricci also spoke of the regular tidal observations carried on at various stations on the coast of Italy, mainly with a view of getting a true level for geodetic purposes. M. H. Duveyrier read an elaborate paper on the remaining problems in African geography, in which he divided unknown Africa into seven great regions: (1) The Sahara and the Libyan Desert; (2) The country between the Joliba and the Guinea Coast; (3) The upper courses of the Binue and Shari; (4) The region behind Cape Guardafui ; (5) The equatorial chain of lofty mountains ; (6) The completion of the basins of the Nile, Congo, and Ogove; (7) The basin of the Cunene. Altogether more than $\mathrm{I}, \infty \infty, 000$ square kilometres remain unexplored, more than one-third of the whole surface of Africa. At the mean rate of discovery since the beginning of the century, this might be covered in about forty-eight years, though the ratio is now so increased that it ought to be done in much less time. A paper by $M$. Maunoir recounted the services done to geography by France since 1800 , and when all put together with the eloquence of a Frenchman, they seem formidable.

News from Capt. 'Tyson's Arctic expedition in the Florence has been brought to Washington by the schooner Helen, which wintered in the same bay on the coast of Cumberland. Meteorological observations were taken most accurately during winter by Mr. Sherman, the physicist of the expedition. Unfortunately the natu-. ralist inflicted on himself a wound when on duty, and was disabled for the greater part of the winter. Capt. Tyson went to Disco to recruit natives, collect goods, and purchase dogs. He fulfilled his duty with his wonted activity and success. But when everything was ready he learned by a message sent from Washington that the preparations were useless, the American Congress having taken its vacation without deliberating upon the report so carefully drawn by the Marine Committee. The brave and accomplished commander of the Florence is now on his way to Washington, where he is expected daily. We are informed that a demonstration will be made against this piece of Parliamentary negligence. This preliminary expedition was entirely fitted out at the expense of Capt. Howgate and his friends.

NEwS has arrived that the Bremen steamer Neptune, Capt. Rasmussen, which left for the $\mathrm{Ob}$, in Siberia, on July $x 6$, reached Hammerfest on the 6th instant with a full cargo of Siberian wheat. The Neptune was laden with all sorts of mercantile goods. She entered the Nadym on August 13 , and had no ice difficulties on the voyage out. "Perhaps in future, when the 